\title{
PS Dependent APP Cleavage Regulates Glucosylceramide Synthase and is Affected in Alzheimer's Disease
}

\author{
Marcus O.W. Grimmª,b Benjamin Hundsdörfera Sven Grösgen ${ }^{a}$ \\ Janine Mett ${ }^{\mathrm{a}}$ Valerie C. Zimmer ${ }^{\mathrm{a}}$ Christoph P. Stahlmann ${ }^{\mathrm{a}}$ Viola J. Haupenthal ${ }^{\mathrm{a}}$ \\ Tatjana L. Rothhaara Johannes Lehmann ${ }^{\mathrm{a}}$ Andreas Pätzold ${ }^{\mathrm{d}}$ Eva G. Zinser ${ }^{\mathrm{a}}$ \\ Heikki Tanilae Jie Shen ${ }^{f}$ Ulrike Müller ${ }^{g}$ Heike S. Grimmª Tobias Hartmann ${ }^{a, b, c}$ \\ aExperimental Neurology, Saarland University, ${ }^{b}$ Neurodegeneration and Neurobiology, Saarland \\ University, 'Deutsches Institut für DemenzPrävention (DIDP), Saarland University, Homburg/Saar, \\ Germany; ${ }^{\circledR}$ Centre for Molecular Biology Heidelberg, INF 282, Heidelberg, Germany; ${ }^{\text {eDepartment of }}$ \\ Neuroscience and Neurology, University of Kuopio, Kuopio, Finland; ${ }^{\mathrm{f} C e n t e r}$ for Neurologic Diseases, \\ Brigham and Women's Hospital, Harvard Medical School, Boston, MA, USA; Institute for Pharmacy and \\ Molecular Biotechnology, INF 364, Heidelberg, Germany
}

\section{Key Words}

Alzheimer's disease • Presenilin • Amyloid precursor protein • Gangliosides • Glucosylceramide synthase

\begin{abstract}
Background: Gangliosides were found to be associated with Alzheimer's disease (AD). Here we addressed a potential function of $\gamma$-secretase (presenilin) dependent cleavage of the amyloid-precursor-protein (APP) in the regulation of ganglioside de novo synthesis. Methods: To identify a potential role of $\gamma$-secretase and APP in ganglioside de novo synthesis we used presenilin (PS) deficient and APP deficient cells and mouse brains, mutated PS as well as transgenic mice and AD post mortem brains. Changes in glucosylceramide synthase (GCS) activity were identified by incorporation of radiolabeled UDP-glucose in glucosylceramide, changes in gene expression via real-time PCR and Western blot analysis. Alterations in ganglioside levels were determined by thin layer chromatography and mass spectrometry. Results: We found that PS and APP deficiency, in vitro and in vivo, resulted in increased GCS gene expression, elevated enzyme activity and thus increased glucosylceramide and total ganglioside level. Using a specific $\gamma$-secretase inhibitor revealed that PS proteolytic activity alters ganglioside homeostasis. By the use of mutated PS causing early onset AD in cell culture and transgenic mice we found that GCS is increased in $A D$, further substantiated by the use of $A D$ post mortem brains, suffering from sporadic AD. Conclusion: APP processing regulates ganglioside de novo synthesis and is affected in AD.
\end{abstract}

M.O.W. Grimm and B. Hundsdörfer contributed equally to this work 


\section{Introduction}

Alzheimer's disease (AD) is a devastating neurodegenerative disorder and the most common form of dementia currently affecting over 35 million people worldwide [1]. Pathological hallmarks of AD are extracellular amyloid plaques, intracellular neurofibrillary tangles and an excessive loss of synapses [2]. The senile plaques mainly consist of 40-42 amino acid (aa) long peptides termed $\beta$-amyloid $(A \beta)$ [3]. $A \beta$ peptides are generated by sequential proteolytic processing of the type-I transmembrane amyloid precursor protein (APP) by two proteases, termed $\beta$ - and $\gamma$-secretase. Beside the generation of A $\beta$ peptides, APP processing generates several further cleavage products, including soluble secreted APP fragments and the APP intracellular domain (AICD) [4], which is released into the cytosol and is discussed to be involved in gene transcription [5].

The $\gamma$-secretase, which catalyzes therelease of A $\beta$ peptides and AICD, is a heterotetrameric protein complex with the presenilins, either presenilin 1 (PS1) or presenilin 2 (PS2), as active subunits [6]. Most mutations leading to familial early-onset AD (FAD) are located in the genes encoding PS1 and PS2 [7]. The processing of APP by $\gamma$-secretase belongs to the mechanism of regulated intramembrane proteolysis (RIP) [8]. Characteristics of RIP are an initial cut outside the membrane followed by a second cleavage inside the membrane, which is performed by secretases that, unlike others, can function inside the hydrophobic lipid environment of cellular membranes. Therefore, cleavage of APP by $\gamma$-secretase is discussed to depend on the lipid composition of cellular membranes. Several lipids, e.g. cholesterol, sphingomyelin, gangliosides, docosahexaenoic acid (DHA) and trans fatty acids, have been shown to alter $\gamma$-secretase cleavage of APP [9-14]. The link between lipid homeostasis and $\mathrm{AD}$ is further supported by lipid changes of e.g. cholesterol, sphingomyelin, ceramide and gangliosides in $\mathrm{AD}$ post mortem brains and transgenic mouse models [15].

Gangliosides are glycosylated sphingolipids containing sialic acids derived from an initial binding of glucose to ceramide generating glucosylceramide (GlcCer) by the glucosylceramide synthase (GCS). By addition of galactose, lactosylceramide (LacCer) is formed. Further, addition of sialic acids and $\mathrm{N}$-acetylgalactosamine leads to gangliosides [16, 17]. Gangliosides are highly enriched in neuronal and glial membranes and involved in the regulation of early development, differentiation and proliferation of these cells [18].

In human brain ganglioside composition and concentration differ between normal aging [19] and pathological aging in AD [20-24]. While some gangliosides are considered to be protective, others like GM1, may increase the risk for AD as they promote amyloidogenic APP processing $[11,25]$. In addition, it has been shown that GM1 binds A $\beta$ and enhances $A \beta$-aggregation and generation of amyloid plaques [26]. Dysfunction of ganglioside homeostasis is found to be associated with inherited diseases that are characterized by accumulation of gangliosides and their precursors in endosomal-lysosomal compartments [27]. Furthermore, it has been shown that accumulation of gangliosides decrease the lysosome-dependent degradation of APP C-terminal fragments [28] and lead to the intraneuronal accumulation of ganglioside-bound $A \beta$ peptides [29].

As gangliosides were consistently found to be associated with $\mathrm{AD}$ [44], we investigated in the present study a potential function of PS-dependent APP processing in the regulation of the ganglioside de novo synthesis.

\section{Material and Methods}

Chemicals and lipids

All used chemicals/cell culture media and lipids were purchased from Sigma (Taufkirchen, Germany) and Avanti Polar Lipids (Avanti Polar Lipids, Alabaster, USA), respectively, if not stated otherwise.

Cell Culture

PS1/2 deficient mouse embryonic fibroblasts (MEF PS1/2 -/-), MEF PS1/2 -/- retransfected with PS1 wildtype (MEF PS1r or MEF PS1wt), MEF PS1/2 -/- retransfected with PS1 A285V (MEF PS1 A285V) or 
Grimm et al.: Glucosylceramide Synthase and Alzheimer's Disease

retransfected with PS1 T354I (MEF PS1 T354I), APP/APLP2 deficient mouse embryonic fibroblasts (MEF APP/APLP2-/-), wildtype mouse embryonic fibroblasts (MEF wt) and COS7 cells stably transfected with APP695wt were cultivated in DMEM containing 10\% FBS (PAN Biotech Aidenbach, Germany) as described previously [11]. For retransfected PS1/2 deficient MEFs, $300 \mu \mathrm{g} / \mathrm{ml}$ Zeocin was added to the cell culture media; for retransfected COS7 cells, additional $400 \mu \mathrm{g} / \mathrm{ml}$ Hygromycin B was used. The $\gamma$-secretase inhibitor X (Calbiochem, Darmstadt, Germany) was incubated in a final concentration of $2 \mu \mathrm{M}$. To determine the effect of AICD (sequence in 1-letter code: KMQQNGYENPTYKFFEQMQN) $(2 \mu \mathrm{M})$ (Genscript Corporation, Piscatway, USA) synthetic peptides were incubated for 9 days in cell culture. Utilizing this method it has been previously shown that AICD is efficiently taken up and biologically active [30, 31].

\section{Human and Murine Brain Material}

Human post mortem brains and correspondent control brain samples were obtained from Brain-net (Munich, Germany) and have been described earlier [32]. Murine APP -/- brain material was obtained from U. Müller (Heidelberg, Germany) [33], conditional PS1/2 -/- mouse brains from J. Shen (Boston, USA) [34], APPswe mouse brains from H. Tanila (Kuopio, Finnland) and PSmutKI brains from T. Bayer (Göttingen, Germany) [35].

\section{Quantitative Real-Time PCR Experiments}

As described previously total RNA was extracted from cells using TRIzol reagent (Invitrogen, Karlsruhe, Germany) according to manufacturer's protocol [36]. $2 \mu \mathrm{g}$ of total RNA was reverse transcribed using High Capacity cDNA Reverse Transcription kit (Life Technologies, Darmstadt, Germany). Quantitative real-time PCR analysis was performed using Fast SYBR Green Master Mix on 7500 Fast Real Time PCR System $(7500$ Fast System SDS Software 1.3.1; Applied Biosystems, Darmstadt, Germany). Changes in gene expression were calculated by 2- $\left(\Delta \Delta \mathrm{C}_{\mathrm{T}}\right)$ method [37], the results were normalized to $\beta$-actin. Calculated standard deviation of the mean was placed on both control and sample bar. The following primers were used: murine: Ugcg: 5'-GGC TCA TAG CCT TTG CTC AG-3' and 5'-TTG CAT GGC AAC TTG AGT AGA-3' ; $\beta$-actin: 5'-CCT AGG CAC CAG GGT GTG AT-3' and 5'-TCT CCA TGT CGT CCC AGT TG-3'; human: Ugcg: 5'-GGC TCA TAG CCT TTG CTC AG-3' and 5'-TTG CAT GGC AAC TTG AGT AGA-3' ; $\beta$-actin: 5'-CTT CCT GGG CAT GGA GTC-3' and 5'-AGC ACT GTG TTG GCG TAC AG-3:

\section{Cell Lysis}

Cells were either lysed chemically or mechanically depending on further use. Chemically, cells were lysed in lysis buffer (0.1\% NP-40, 0.1\% Triton-X 100, 10mM Tris, 2mM EDTA) with protease inhibitor (Roche Diagnostics, Grenzach-Wyhlen, Germany) as previously described [38]. Mechanical lysis was performed by using a PotterS homogenizer (B. Braun, Melsungen, Germany).

\section{Determination of protein concentration}

Determination of protein concentration was performed according to Smith et al. [39]. Samples were adjusted to equal protein amount prior to use for experiments.

\section{Western Blot Analysis}

Samples were separated on 10-20\% Tris-Tricine gels (Invitrogen, Karlsruhe, Germany) and transferred onto nitrocellulose membranes (Whatman, Dassel, Germany). For Western Blot analysis the primary antibody anti-GCS ab98030 was used (Abcam, Cambridge, UK). Proteins were detected by ECL-method (Perkin Elmer, Rodgau -Jügesheim, Germany) and densitometrically quantified by Image Gauge software.

\section{Lipid Extraction}

A modified Bligh and Dyer $[31,40]$ method was utilized to extract GlcCer to measure GCS activity. After stopping the GCS activity by freezing in liquid nitrogen, $3.75 \mathrm{ml} \mathrm{CHCl}_{3}: \mathrm{MeOH}: \mathrm{HCl}$ (1: 2: 0.06; v/v/v) was added and vortexed for $1 \mathrm{~h}$ at RT. Then $1.25 \mathrm{ml} \mathrm{CHCl}_{3}$ was added and vortexed for $1 \mathrm{~h}$. After adding $1.25 \mathrm{ml}$ $\mathrm{H}_{2} \mathrm{O}$ and $1.25 \mathrm{ml} \mathrm{CHCl}_{3}$ and short mixing, samples were centrifuged for $10 \mathrm{~min}$ at 5000rpm. $\mathrm{The} \mathrm{CHCl}_{3}$ phase containing GlcCer was isolated in another glass tube and evaporated under nitrogen flow. $1 \mathrm{ml}_{2} \mathrm{O}$ and $3.75 \mathrm{ml} \mathrm{CHCl}_{3}: \mathrm{MeOH}: \mathrm{HCl}(1: 2: 0.06 ; \mathrm{v} / \mathrm{v} / \mathrm{v})$ was added to the lipid film. The extraction cycle was repeated one time and the resulting $\mathrm{CHCl}_{3}$ phase was measured as described below. 


\section{Determination of GCS Activity}

After homogenisation of cells, GCS activity reaction was started with $1.5 \mathrm{mg}$ protein per sample in $360 \mu$ l washbuffer $(10 \mathrm{mM}$ Tris/HCl pH7.4, $50 \mathrm{mM} \mathrm{NaCl})$ and $40 \mu \mathrm{l}$ starting buffer $\left(860 \mu \mathrm{M} \mathrm{C}_{6}\right.$-Ceramide in $1 \mathrm{mM} \mathrm{BSA}$ ) containing $0.4 \mu \mathrm{Ci} 3 \mathrm{H}$-UDP-glucose and stopped after $120 \mathrm{~min}$ [17]. After isolation of the lipid phase as described above, $3 \mathrm{ml}$ szintilation solution (Perkin Elmer, Rodgau-Jügesheim, Germany) was added, mixed and radioactivity was measured by a Tri-Carb 2800TR (Perkin Elmer, Rodgau-Jügesheim, Germany) $[31,41-43]$. The assay was validated using a specific GCS inhibitor, DL-PDMP $(5 \mu \mathrm{M})$. In presence of DLPDMP, GCS activity was reduced to $11.0 \%( \pm 7.4 \%, \mathrm{p} \leq 0.001)$.

\section{Ganglioside Isolation}

Isolation of gangliosides from MEFs was performed by using a modified Bligh and Dyer method. After desalting the lipids by a reversed-phase cartridge (Waters Oasis, Eschborn, Germany) according to Whitfield et al. [44] the concentrated ganglioside extract was applied to silica gel thin-layer chromatography (TLC) plates (Merck, Darmstadt, Germany) and separated by using $\mathrm{CHCl}_{3}: \mathrm{MeOH}: \mathrm{H}_{2} \mathrm{O}-\mathrm{CaCl}_{2} 0.2 \%$ (60: 35: $8 ; \mathrm{v} / \mathrm{v}$ ) as solvent system [45]. Gangliosides were visualized by iodine and identified by their Rf-values and available standards. Densitometric quantification was performed using Image Gauge software. All detectable gangliosides were integrated to determine total ganglioside level.

To validate the use of iodine to stain gangliosides, a concentration range of GM1 (1 to $40 \mathrm{nM} \mathrm{GM1)}$ separated on TLC was either stained by iodine or by $\alpha$-naphthol (Fig. $6 \mathrm{~A}$ and B). Gangliosides GM3, GM1, GD3, GD1a, GD1b and GT1b were identified by ganglioside standards loaded on each TLC and the corresponding Rf-values.

\section{Mass Spectrometry qTOF}

For mass spectrometry lipids were measured using a qTOF Pulsar mass spectrometer (PE SCIEX, Weiterstadt, Germany) equipped with a nano-ESI source (MDS Protana, Odense, Denmark) in positive mode. Lipids were extracted from $250 \mu \mathrm{g}$ protein by Bligh and Dyer method. As external standard 1.8pmol 1,2-dimyristonyl-sn-glycero-3-phosphocholine-1,1,2,2- $\Delta 4$ was added and produced a reference peak of $\mathrm{m} / \mathrm{z}=682.5 \mathrm{in}$ TOF positive spectra. Measurement was performed by using a $700 \mathrm{~V}$ potential and $40 \mathrm{eV}$ declustering potential. TOF positive range was set to $\mathrm{m} / \mathrm{z}=600-900$ and stable spectra were recorded for $2 \mathrm{~min}$. For precursor ion scans TOF range was set to $\mathrm{m} / \mathrm{z}=170-270$ and $60 \mathrm{eV}$ collision energy $[10,46]$. Data were normalized to an internal standard (PC16:0 / 18:1) and shown as \% of control. Absolute values depend on injection or flow rate and vary between each experiment making it necessary to normalize the values to a standard (Fig. 6 C). To make sure that the correct peak was quantified, we made a fragmentation of the GlcCer 24:1 peak (m/z=810) shown in Fig. 6 D.

\section{Determination of $\gamma$-secretase activity}

Determination of $\gamma$-activity was performed as described before $[11,12,14]$. Briefly, cells were washed three times with ice-cold phosphate-buffered saline (PBS), scraped off in sucrose buffer $(10 \mathrm{mM}$ Tris/HCl pH7.4 including 1mM EDTA and 200mM sucrose) and homogenized using a PotterS at maximum speed (25 strokes). After protein adjustment to $1 \mathrm{mg}$, the samples were centrifuged at $900 \mathrm{rcf}$ for $10 \mathrm{~min}$ at $4^{\circ} \mathrm{C}$ and the obtained post-nuclear fractions were ultracentrifuged at $55000 \mathrm{rpm}$ for $75 \mathrm{~min}$ at $4^{\circ} \mathrm{C}$. Pelleted membranes were resuspended using cannulae with decreasing diameter in $300 \mu$ l sucrose buffer. The volume was portioned in 96well plates $(100 \mu \mathrm{l}$, equates to $250 \mu$ g protein) and $\gamma$-secretase substrate (Farmery 2003 JBC

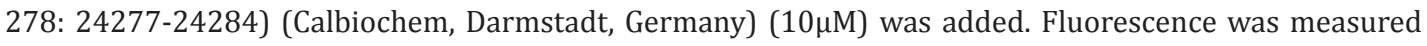
for $3 \mathrm{~h}$ under light exclusion using excitation at $355 \pm 10 \mathrm{~nm}$ and fluorescence detection at $440 \pm 10 \mathrm{~nm}$ or $345 \pm 5 \mathrm{~nm} / 500 \pm 2.5 \mathrm{~nm}$ respectively. Assay specificity is $>90 \%$ for $\gamma$-secretase activity assay, and was validated using $\gamma$-secretase inhibitor L-658458 (Merck, Darmstadt, Germany).

\section{Statistical Analysis}

All quantified data presented here are based on an average of at least three independent experiments. Error bars represent standard deviation of the mean. Statistical significance was determined by two-tailed Student's t-test; significance was set at ${ }^{*} \mathrm{p} \leq 0.05,{ }^{* *} \mathrm{p} \leq 0.01$ and ${ }^{* * *} \mathrm{p} \leq 0.001$. 


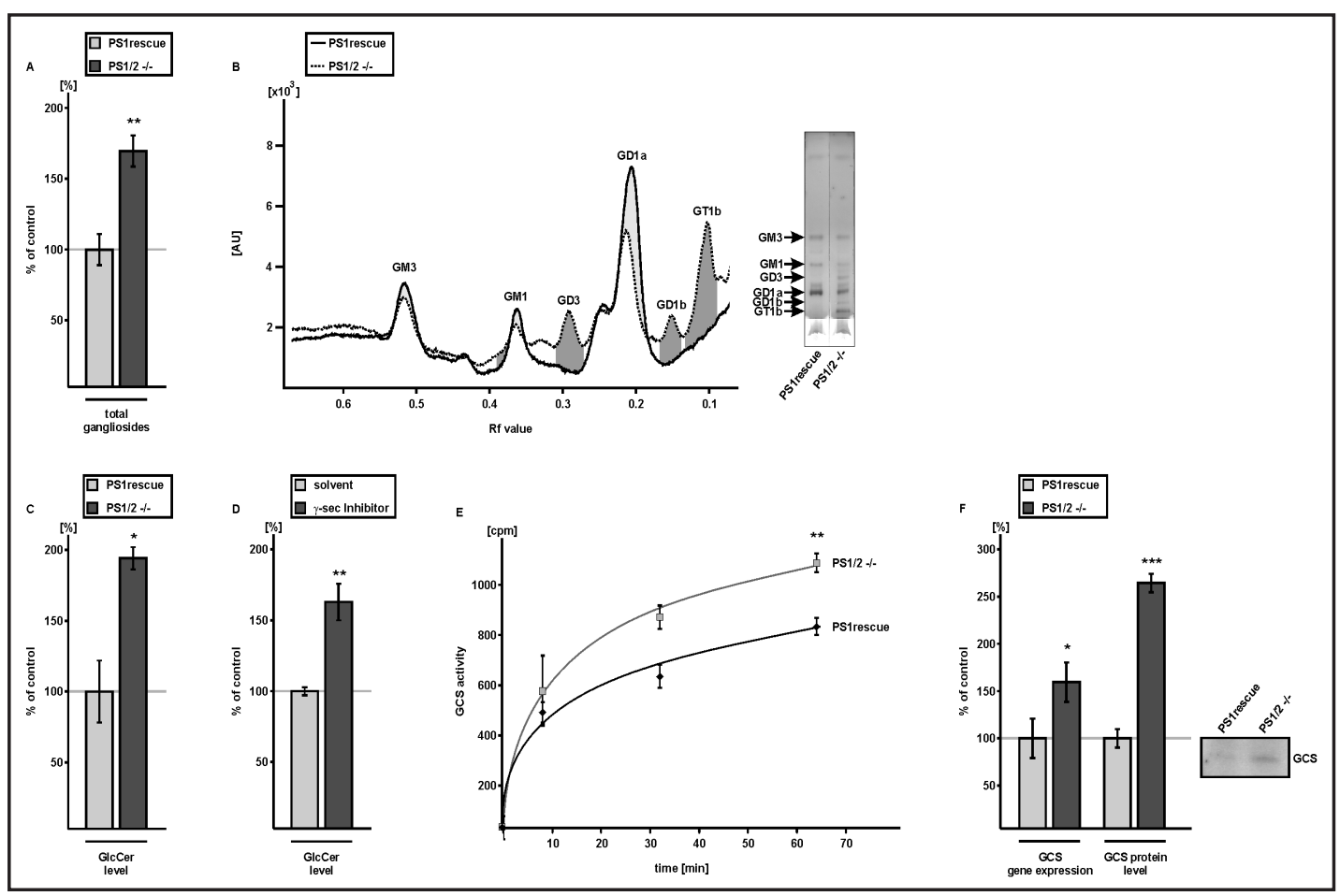

Fig. 1. PS proteolytic activity regulates ganglioside de novo synthesis. A) Total ganglioside level in MEF PS1/2 -/- and PS1 retransfected MEF PS1/2 -/- (MEF PS1rescue) cells were analyzed by thin layer chromatography. B) Representative thin layer chromatography and densitogram of MEF PS1/2 -/- versus PS1 retransfected MEF PS1/2 -/- cells. C) GlcCer level in MEF PS1/2 -/- and PS1 rescue cells were analyzed by mass spectrometry. D) COS7 cells stably transfected with APP695 were incubated with $\gamma$-secretase inhibitor $\mathrm{X}(2 \mu \mathrm{M})$ and GlcCer level were analyzed by mass spectrometry. E) GCS activity in MEF PS1/2 -/- cells and PS1rescue cells was determined by the incorporation of UDP-glucose in GlcCer. F) GCS gene expression and GCS protein level in MEF PS1/2 -/- and PS1rescue cells. Gene expression of GCS was analyzed by RTPCR and the protein level of GCS was determined by Western blot analysis using the antibody ab98030. A representative WB is shown. Asterisks show the statistical significance $\left({ }^{*} \mathrm{p} \leq 0.05,{ }^{* *} \mathrm{p} \leq 0.01\right.$ and ${ }^{* * *} \mathrm{p} \leq 0.001$, n.s. = not significant). All quantified data represent an average of at least three independent experiments. Error bars represent standard deviation of the mean.

\section{Results}

Presenilin increases ganglioside synthesis by affecting glucosylceramide synthase (GCS)

As mentioned above, it has been shown that ganglioside homeostasis is altered during aging $[19,20]$ and in line with clinical and epidemiological observations, that link lipids with $\mathrm{AD}$, gangliosides were found to be associated with AD [47].

To investigatea potential role of PSand $\gamma$-secretase in gangliosidemetabolism, weanalyzed PS1 and PS2 deficient mouse embryonic fibroblasts (MEF PS1/2 -/-) and PS1 retransfected control cells (MEF PS1r). As PS knock-out is perinatally lethal at embryonic day 9.5 [48] and the corresponding PS1/2 -/- MEFs were therefore generated from mouse fetus compared to wildtype mouse embryonic fibroblasts which were obtained from new born mice, we decided to retransfect MEF PS1/2-/- cells with PS to obtain clonal homogeneity. This is especially important for the analysis of gangliosides as gangliosides have been shown to be altered during early development [20,49]. In absence of PS, total gangliosides were significantly increased $(171.8 \%, \pm 11.4 \%, \mathrm{p}=0.005)$ (Fig. $1 \mathrm{~A}$ ). As already shown in a previous study [11], deletion of PS1 and PS2 showed a strong increase for $b$-series gangliosides GD3, GD1b and GT1b whereas $a$-series gangliosides GM3, GM1 and GD1a were decreased (Fig. 1 B), resulting 


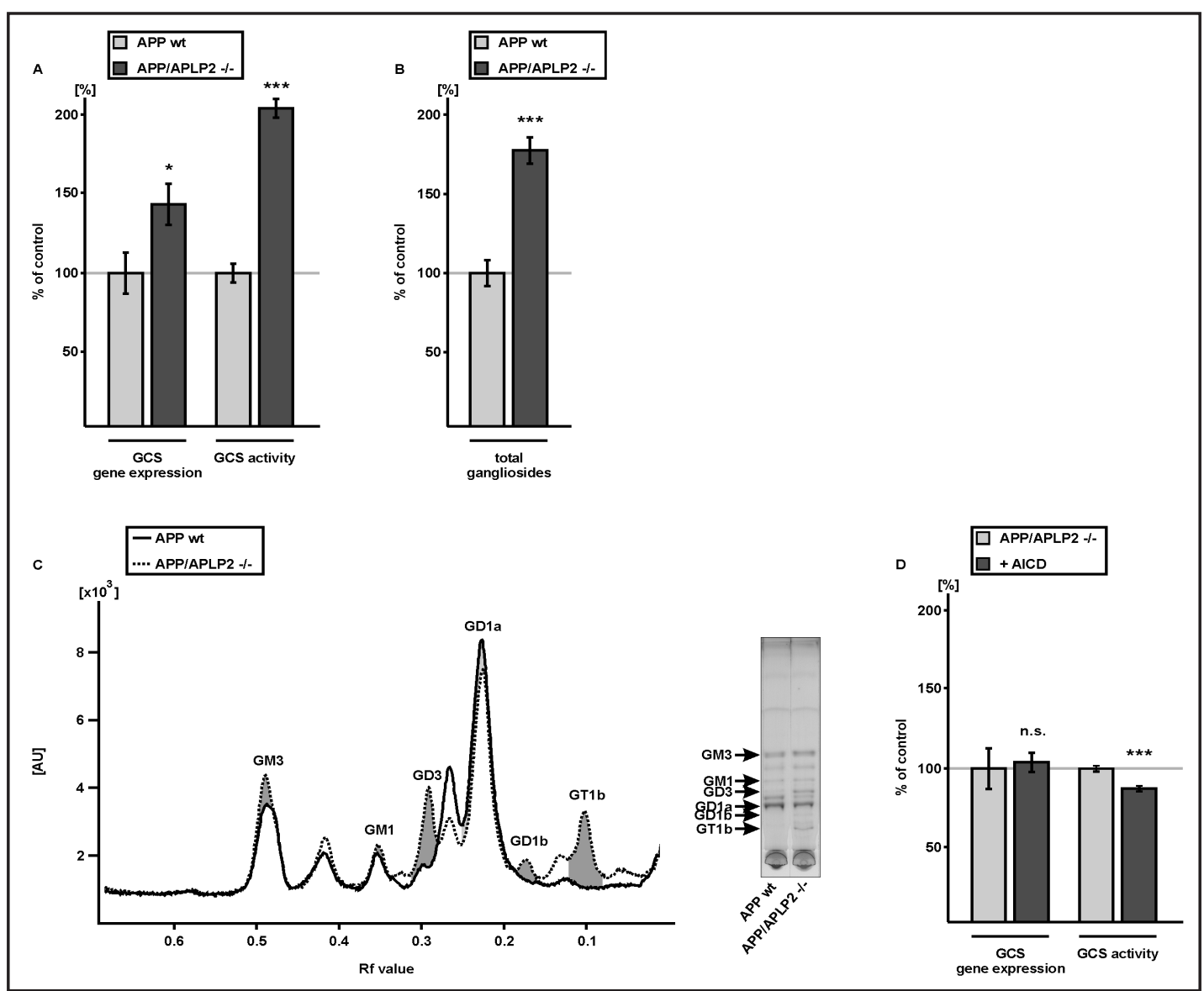

Fig. 2. Analysis of ganglioside de novo synthesis in APP/APLP2 deficient mouse embryonic fibroblasts. A) GCS activity and GCS gene expression in APP/APLP2 -/- and APPwt cells. GCS activity and GCS gene expression were determined as described for Fig. 1. B) Total ganglioside level isolated from APP/APLP2 -/- and APPwt cells determined by thin layer chromatography. C) Representative thin layer chromatography and densitogram of APP/APLP2 -/- versus APPwt cells. D) APP/APLP2 -/- cells were incubated with AICD peptides. GCS gene expression and GCS activity was determined as described for Fig. 1. (A, B, D) Illustration and statistical analysis as described for Fig. 1.

in a strong increase in the ratio of $b / a$-series gangliosides (Table 4). More detailed analysis by mass spectrometry revealed that the alterations in total gangliosides were accompanied by a similar increase in the GlcCer level $(197.5 \%, \pm 9.65 \%, p=0.034)$ (Fig. 1 C). In order to investigate whether the observed changes in total ganglioside and GlcCer level are caused by the lack of the proteins PS1 and PS2 itself or are dependent on $\gamma$-secretase proteolytic activity catalyzed by PS1 or PS2 as active site of the $\gamma$-secretase complex [42, 43], we incubated COS7 cells stably expressing APP695wt with a specific $\gamma$-secretase inhibitor. In line with the results obtained by PS deficiency, incubation of COS7 cells with $2 \mu \mathrm{M} \gamma$-secretase inhibitor X also resulted in an increased GlcCer level (165.0\%, $\pm 13.3 \%, p=0.009)$ (Fig. $1 \mathrm{D}$ ), suggesting that the observed changes in GlcCer and total gangliosides are indeed due to the lack of proteolytic $\gamma$-secretase activity.

An important step in ganglioside synthesis is catalyzed by the GCS leading to the turnover of ceramide to GlcCer [16]. Both, the increase in total gangliosides and especially in GlcCer suggest that the observed effect could be caused by increased GCS activity. Therefore we measured GCS activity in dependence on PS, by monitoring the incorporation of radioactive labeled UDP-glucose in GlcCer. As expected, GCS activity was increased in PS1/2 deficient cells $(139.2 \%, \pm 5.6 \%, p=0.009)$ (Fig. $1 \mathrm{E}$ ). In accordance with elevated GCS activity, gene 
Fig. 3. Altered ganglioside homeostasis in APP or PS knock-out mouse brains. A) GlcCer level and GCS gene expression in APP-deficient mouse brains (only males). B) GlcCer level in conditional PS1/2 -/- mouse brains (only males). (A, B) GlcCer level were analyzed by mass spectrometry. Illustration and statistical analysis as described for Fig. 1.

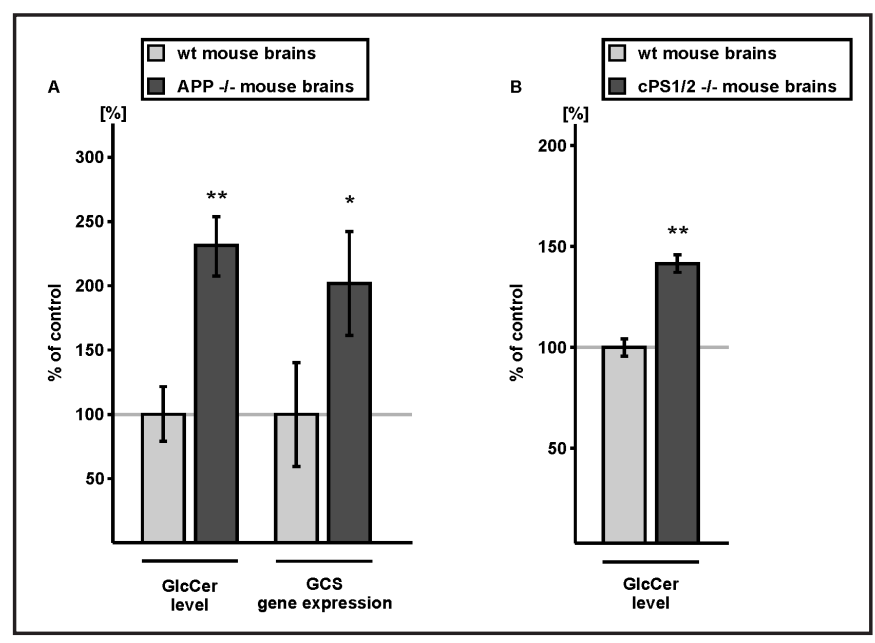

expression analyzed by real time (RT)-PCR as well as the protein level of the GCS determined by western blot (WB) analysis were also increased in absence of PS (gene expression: 162.3\%, $\pm 21.8 \%, \mathrm{p}=0.021$, protein level: $256.3 \%, \pm 9.6 \%, \mathrm{p} \leq 0.001$ ) (Fig. $1 \mathrm{~F}$ ).

Elevated GCS activity in absence of $\gamma$-secretase is mediated by the $\gamma$-secretase substrate APP

The strong increase in the GlcCer level, both in PS1/2 deficient cells and in cells treated with $\gamma$-secretase inhibitor, indicate that the proteolytic activity of PS is responsible for the observed increase in GCS activity. Beside APP, the $\gamma$-secretase is known to cleave more than 60 substrates, including e.g. the Notch-receptor, ErbB4, CD44, LRP1 and jagged [50]. Because of the strong link of gangliosides with AD we evaluated whether APP is the substrate of the $\gamma$-secretase, which mediates the alterations in GCS activity, resulting in the observed changes in GlcCer and total ganglioside level. Analysis of MEFs devoid of APP and the APP like protein 2 (APLP2) (MEF APP/APLP2-/-) showed an increase of GCS activity to $207.5 \%( \pm 6.0 \%$, p $\leq 0.001$ ) (Fig. 2 A). Comparable to the findings obtained in absence of PS, the elevation in GCS activity in APP/APLP2 deficient cells was accompanied by an increase in GCS gene expression to $144.8 \%( \pm 13.4 \%, p=0.005)$ (Fig. 2 A). Moreover, in line with the results in MEF PS1/2 -/-, total gangliosides and the ratio of $b / a$-series gangliosides were increased in absence of the APP family $(180.1 \%, \pm 8.5 \%, \mathrm{p} \leq 0.001)$ (Fig. $2 \mathrm{~B}$ and $\mathrm{C}$ and Table 4 ).

On the other hand, we observed no significant changes on GCS gene expression in APP/APLP2 deficient cells treated with AICD peptides (Fig. 2 D). However, GCS activity was reduced to $86.9 \%$ when APP/APLP2-deficient cells were incubated with AICD peptides $(86.9 \% \pm 0.36 \%, p \leq 0.001)$ (Fig. $2 \mathrm{D})$, indicating that the APP cleavage product AICD is involved in GCS regulation.

GlcCer level are increased in mouse brains devoid of PS or APP

To investigate whether our results obtained in cell culture experiments, using MEFs or COS7 cells, can also be observed in vivo, we determined the GlcCer level of mouse brains lacking either APP or PS. Whereas APP knock-out mice are still viable [51, 52], PS1/2 knockout mice are lethal at e9.5 [48]. Therefore we used brains from conditional PS1 knock-out mice, crossed to PS2 knock-out mice (cPS1/2-/-) [34]. In these viable mice, PS1 remains expressed in some neurons and other cells [53] and brain A $\beta$ levels in these mice are reduced to $20-50 \%$, depending on age and $A \beta$ species [54]. APP knock-out mouse brains showed a strong increase in the GlcCer level to $231.4 \%$ compared to wildtype (wt) animals $( \pm 23.1 \%, p=0.007)$ and in line with the results obtained in cell culture experiments GCS gene expression was also significantly increased in mouse brains devoid of APP $(202.0 \%$, 

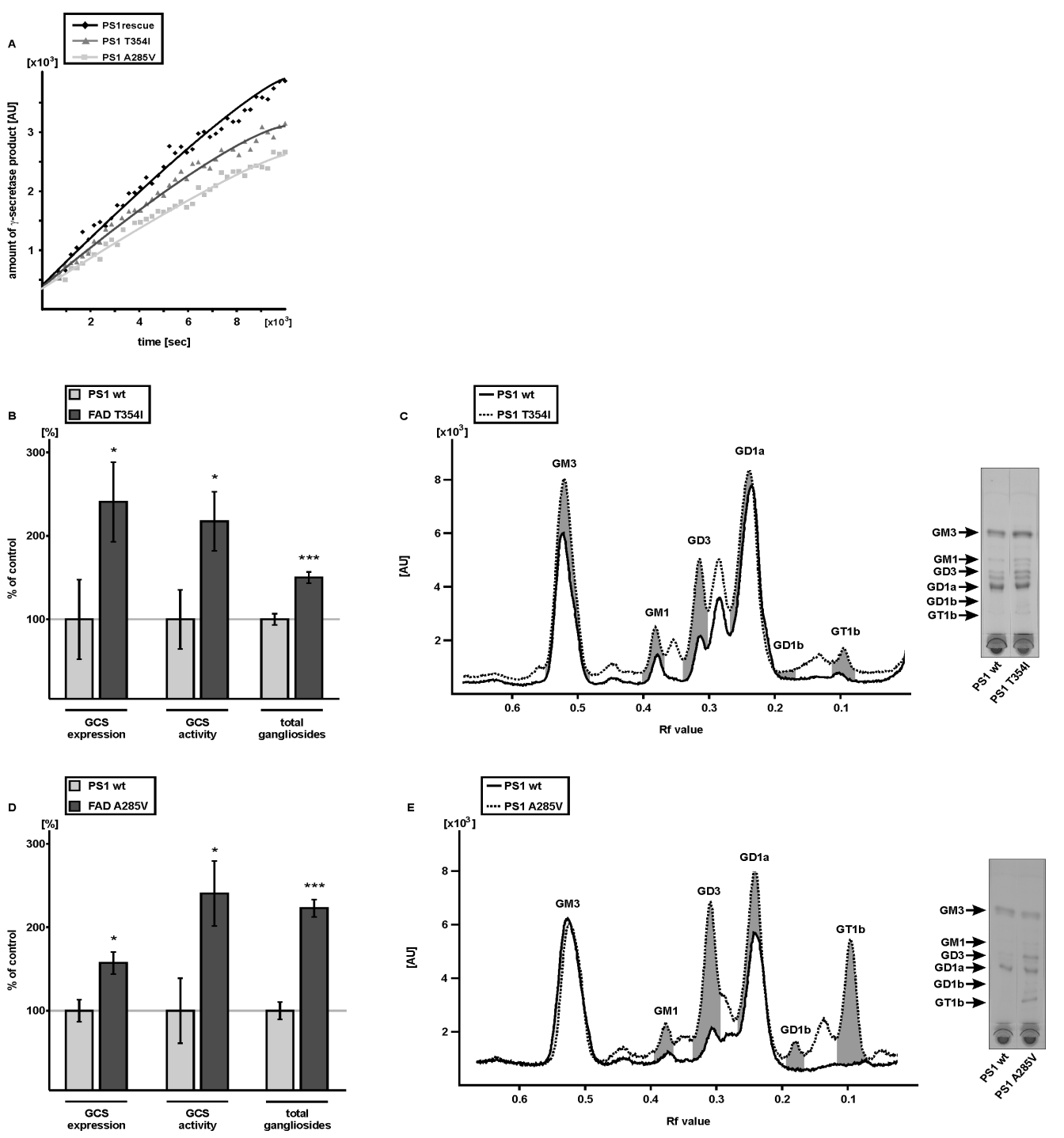

Fig. 4. Ganglioside synthesis is altered in PS mutations causing familial early onset AD. A) $\gamma$-secretase-activity in MEF PS1rescue and MEF PS1-FAD cells (PS1 T354I, PS1 A285V). GCS gene expression, activity and total ganglioside level in MEF PS1/2 -/- cells retransfected with B) PS1-FAD-mutation T354I (FAD T354I) and D) A285V (FAD A285V). Representative thin layer chromatography and densitogram of PS1rescue versus C) FAD T354I and E) FAD A285V cells. (A, B, D) Determination of GCS gene expression, activity and total gangliosides as described for Fig. 1. Illustration and statistical analysis as described for Fig. 1.

$\pm 40.5 \%$, p=0.045) (Fig. 3 A). Additionally, we observed an increase in the GlcCer level in conditional PS knock-out mice to $142.9 \%$ ( $\pm 4.5 \%$, p=0.002) (Fig. 3 B).

\section{PS mutations increase GCS activity and ganglioside level}

As mentioned above several studies reported a change in the ganglioside pattern in human post mortem AD brains [22, 24, 55]. Beside the sporadic form of AD, more than 200 mutations in PS1 or PS2 [56, 57] are known to cause familial Alzheimer's disease (FAD), characterized by an earlier disease onset. Here, we investigated whether the PS1 mutations T354I and A285V affect ganglioside homeostasis. We selected these PS1 mutations because previous studies already revealed that PS1 T354I and A285V affect sphingolipid homeostasis 


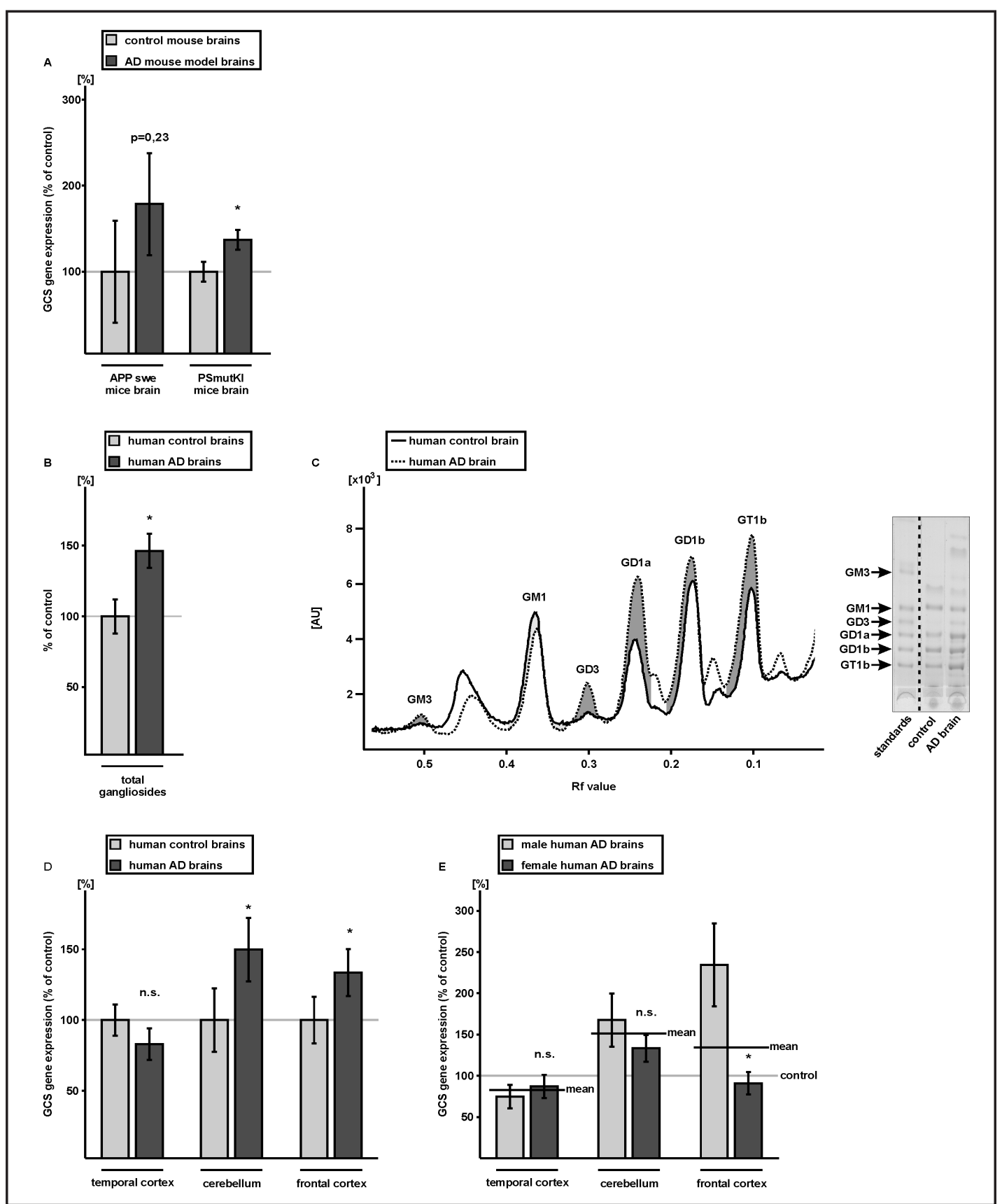

Fig. 5. GCS is affected in AD transgenic mice and human AD post mortem brains. A) GCS gene expression in brains of an APPswe (only males) and PSmutKI (only males) AD mouse model. B) Total ganglioside level in human post mortem AD brains of males. C) A representative thin layer chromatography and densitometric quantification of post mortem control and AD brains. D) GCS gene expression in temporal cortex, cerebellum and frontal cortex of human post mortem AD brains. E) Gender effect in GCS gene expression in human AD brain. (A, B, D, E) Analysis and statistical significance as described for Fig. 1.

$[10,31]$. Furthermore, both mutations show a reduced $\gamma$-secretase activity (Fig. $4 \mathrm{~A}$ ) compared to PS1 wt. Because our results, obtained with $\gamma$-secretase inhibitor treated COS7 cells or with PS deficient cells, suggest that $\gamma$-secretase activity regulates GCS and therefore GlcCer and total ganglioside level, we retransfected PS1/2 deficient cells with PS1 wt or PS1 FAD mutations. To exclude that potential changes in ganglioside homeostasis are caused by altered 
Table 1. List of all human post mortem brains used. AD = Alzheimer's disease, $\mathrm{F}=$ female, $\mathrm{M}=$ male. Classification according to CERAD (Consortium to Establish A Registry for Alzheimer's Disease) and Braak\&Braak. PM = post mortem delay

\begin{tabular}{|c|c|c|c|c|c|c|}
\hline \multirow[b]{2}{*}{$\#$} & \multicolumn{6}{|c|}{ List of all human post mortem brains used } \\
\hline & NP-Diagnosis & sex & age & CERAD & $\mathrm{B} \& \mathrm{~B}$ & PM delay \\
\hline \#1 & control & $\mathrm{F}$ & 88 & B & I-II & $22 \mathrm{~h}$ \\
\hline \#2 & control & $\mathrm{F}$ & 77 & $\mathrm{C}$ & II & $33 \mathrm{~h}$ \\
\hline \#3 & control & $\mathrm{F}$ & 75 & B & III-IV & $48 \mathrm{~h}$ \\
\hline \#4 & control & $\mathrm{F}$ & 76 & $\mathrm{C}$ & III-IV & $20 \mathrm{~h}$ \\
\hline \#5 & control & $\mathrm{F}$ & 85 & 0 & I & $24 \mathrm{~h}$ \\
\hline \#6 & control & $\mathrm{F}$ & 80 & 0 & III-IV & $26 h$ \\
\hline \#7 & control & $\mathrm{F}$ & 77 & A & II & $33 \mathrm{~h}$ \\
\hline \#8 & control & $\mathrm{F}$ & 83 & 0 & II & $23 \mathrm{~h}$ \\
\hline \#9 & control & M & 75 & 0 & II & $12 \mathrm{~h}$ \\
\hline \#10 & control & M & 63 & 0 & I & $27 \mathrm{~h}$ \\
\hline \#11 & control & M & 71 & 0 & $0-I$ & $24 \mathrm{~h}$ \\
\hline \#12 & control & M & 85 & B & III-IV & $48 \mathrm{~h}$ \\
\hline \#13 & control & M & 87 & 0 & I-II & $49 h$ \\
\hline$\# 14$ & control & M & 61 & 0 & 0 & $50 \mathrm{~h}$ \\
\hline \#15 & AD & $\mathrm{F}$ & 82 & $\mathrm{C}$ & V & $37,5 \mathrm{~h}$ \\
\hline \#16 & AD & $\mathrm{F}$ & 65 & $\mathrm{C}$ & $\mathrm{V}-\mathrm{VI}$ & $48 \mathrm{~h}$ \\
\hline$\# 17$ & $\mathrm{AD}$ & $\mathrm{F}$ & 67 & $\mathrm{C}$ & V-VI & $24 \mathrm{~h}$ \\
\hline \#18 & $\mathrm{AD}$ & $\mathrm{F}$ & 82 & $\mathrm{C}$ & V-VI & n.d. \\
\hline \#19 & AD & $\mathrm{F}$ & 68 & $\mathrm{C}$ & VI & n.d. \\
\hline$\# 20$ & $\mathrm{AD}$ & $\mathrm{F}$ & 78 & $\mathrm{C}$ & V-VI & n.d. \\
\hline$\# 21$ & AD & $\mathrm{F}$ & 85 & $\mathrm{C}$ & III & n.d. \\
\hline$\# 22$ & $\mathrm{AD}$ & $\mathrm{F}$ & 85 & C & IV & n.d. \\
\hline$\# 23$ & $\mathrm{AD}$ & $\mathrm{F}$ & 73 & $\mathrm{C}$ & V-VI & $24 \mathrm{~h}$ \\
\hline$\# 24$ & $\mathrm{AD}$ & $\mathrm{F}$ & 76 & $\mathrm{C}$ & V-VI & $26 \mathrm{~h}$ \\
\hline$\# 25$ & $\mathrm{AD}$ & $\mathrm{F}$ & 88 & $\mathrm{C}$ & VI & n.d. \\
\hline$\# 26$ & $\mathrm{AD}$ & $\mathrm{F}$ & 78 & $\mathrm{C}$ & VI & $4 \mathrm{~h}$ \\
\hline$\# 27$ & $\mathrm{AD}$ & $\mathrm{F}$ & 78 & $\mathrm{C}$ & VI & $14 \mathrm{~h}$ \\
\hline \#28 & AD & $\mathrm{F}$ & 88 & $\mathrm{C}$ & V & $36 \mathrm{~h}$ \\
\hline \#29 & AD & $\mathrm{F}$ & 80 & $\mathrm{C}$ & V & $48 \mathrm{~h}$ \\
\hline \#30 & $A D$ & $\mathrm{~F}$ & 75 & $\mathrm{C}$ & VI & $12 \mathrm{~h}$ \\
\hline \#31 & AD & $\mathrm{F}$ & 79 & $\mathrm{C}$ & V & $20 \mathrm{~h}$ \\
\hline \#32 & $\mathrm{AD}$ & $M$ & 80 & $\mathrm{C}$ & V & $24 \mathrm{~h}$ \\
\hline \#33 & $\mathrm{AD}$ & $\mathrm{M}$ & 73 & $\mathrm{C}$ & V-VI & $14 \mathrm{~h}$ \\
\hline$\# 34$ & AD & M & 74 & $\mathrm{C}$ & $\mathrm{V}-\mathrm{VI}$ & $25 \mathrm{~h}$ \\
\hline \#35 & AD & M & 75 & C & VI & n.d. \\
\hline$\# 36$ & $\mathrm{AD}$ & M & 83 & C & VI & $20 \mathrm{~h}$ \\
\hline \#37 & AD & M & 62 & C & VI & n.d. \\
\hline \#38 & $\mathrm{AD}$ & M & 87 & $\mathrm{C}$ & $\mathrm{V}$ & n.d. \\
\hline$\# 39$ & $\mathrm{AD}$ & M & 87 & C & V & $39 \mathrm{~h}$ \\
\hline$\# 40$ & $\mathrm{AD}$ & M & 83 & $\mathrm{C}$ & V & $48 \mathrm{~h}$ \\
\hline$\# 41$ & $\mathrm{AD}$ & M & 76 & B & $\mathrm{V}$ & $21 \mathrm{~h}$ \\
\hline \#42 & AD & M & 80 & C & V & $22 \mathrm{~h}$ \\
\hline$\# 43$ & $\mathrm{AD}$ & M & 70 & $\mathrm{C}$ & VI & $13 \mathrm{~h}$ \\
\hline$\# 44$ & AD & M & 83 & C & VI & $39 \mathrm{~h}$ \\
\hline
\end{tabular}

Table 2. Mean values ( \pm standard deviation) and significance (pvalue) for age for controls and $A D$ cases. No significant changes were observed

\begin{tabular}{lccc}
\hline & age & SD & $\mathrm{p}=$ \\
\hline control (M+F) & 77,4 & 8,3 & \\
AD (M+F) & 78,0 & 6,9 & 0,788 \\
control (M) & 73,7 & 10,9 & \\
AD (M) & 77,9 & 7,2 & 0,321 \\
control (F) & 80,1 & 4,7 & \\
AD (F) & 78,1 & 6,9 & 0,454 \\
control (M) & 73,7 & 10,9 & \\
control (F) & 80,1 & 4,7 & 0,155 \\
AD (M) & 77,9 & 7,2 & \\
AD (F) & 78,1 & 6,9 & 0,959 \\
\hline
\end{tabular}

Table 3.Mean values ( \pm standard deviation) and significance (p-value) for the post mortem (pm) delay for controls and AD cases. No significant changes were observed. Time of pm-delay is only known for $70 \%$ of all cases

\begin{tabular}{lccc}
\hline & hours & SD & $\mathrm{p}=$ \\
\hline control (M+F) & 31,4 & 12,5 & \\
AD (M+F) & 26,6 & 12,8 & 0,285 \\
control (M) & 35,0 & 16,1 & \\
AD (M) & 26,5 & 11,6 & 0,24 \\
control (F) & 28,6 & 9,2 & \\
AD (F) & 26,7 & 14,4 & 0,742 \\
control (M) & 35,0 & 16,1 & \\
control (F) & 28,6 & 9,2 & 0,366 \\
AD (M) & 26,5 & 11,6 & \\
AD (F) & 26,7 & 14,4 & 0,975 \\
\hline
\end{tabular}

Table 4. ratio of $b / a$-series gangliosides

\begin{tabular}{lccc}
\hline cell-line & {$[\%]$} & SD [\%] & $\mathrm{p}=$ \\
\hline PS1/2 -/- vs. PS1res & 485,5 & 56,7 & $<0,001$ \\
APP/APLP2 -/- vs. APPwt & 373,0 & 13,8 & $<0,001$ \\
A285V vs. PS1res & 322,8 & 27,5 & 0,001 \\
T354I vs. PS1res & 168,4 & 15,3 & 0,013 \\
\hline
\end{tabular}

expression levels of PS1 wt or mutated PS, we used for these experiments retransfected cells having a similar expression level of PS1 wt and PS1 FAD mutations. Both PS1 FAD mutations, T354I and A285V, showed a significant increase in GCS expression, resulting in a significantly elevated GCS activity and total ganglioside level (T354I: GCS expression: $247.7 \% \pm 49.9 \%$, $\mathrm{p}=0.042$; GCS activity: $223.3 \% \pm 37.3 \%$, $\mathrm{p}=0.03$; total gangliosides: $152.7 \% \pm 7.0 \%, \mathrm{p} \leq 0.001$ ) (Fig. 4 B and C) (A285V: GCS expression: $160.2 \% \pm 13.8 \%$, p=0.012; GCS activity: $247.3 \%$, $\pm 40.9 \%$, $\mathrm{p}=0.023$; total gangliosides: $229.0 \%, \pm 10.8 \%$, $\mathrm{p} \leq 0.001$ ) (Fig. $4 \mathrm{D}$ and $\mathrm{E}$ ). As already obtained for PS-deficient and APP/APLP2-deficient cells, the ratio of $b / a$-series gangliosides was increased (Table 4), possibly caused by the reduced $\gamma$-secretase activity observed for PS1 T354I and PS1 A285V.

GCS is affected in vivo in transgenic mice and human AD post mortem brains

In vivo, similar results were obtained by analyzing transgenic $\mathrm{AD}$ mouse brains, where PS mutations have been knocked in (PSmutKI) [35]. GCS expression was increased to $138.8 \%$ ( $\pm 12.2 \%, p=0.019$ ) (Fig. 5 A). Interestingly, these findings might not be restricted to PS FAD 
Fig. 6. Control experiments of GlcCer and ganglioside detection. A) Range of linear detection of GM1 measured by thin layer chromatography utilizing iodine. B) Linear range of ganglioside detection by iodine, mass spectrometry and $\alpha$-naphthol (iodine: $\mathrm{R}^{2}=0.99 ; \quad$ mass spectrometry: $\mathrm{R}^{2}=0.98 ; \quad \alpha$-naphthol: $\left.\quad \mathrm{R}^{2}=0.97\right)$. C) Exemplary mass spectrometry profile of GlcCer 24:1 compared to standard. D) Fragmentation of GlcCer 24:1.

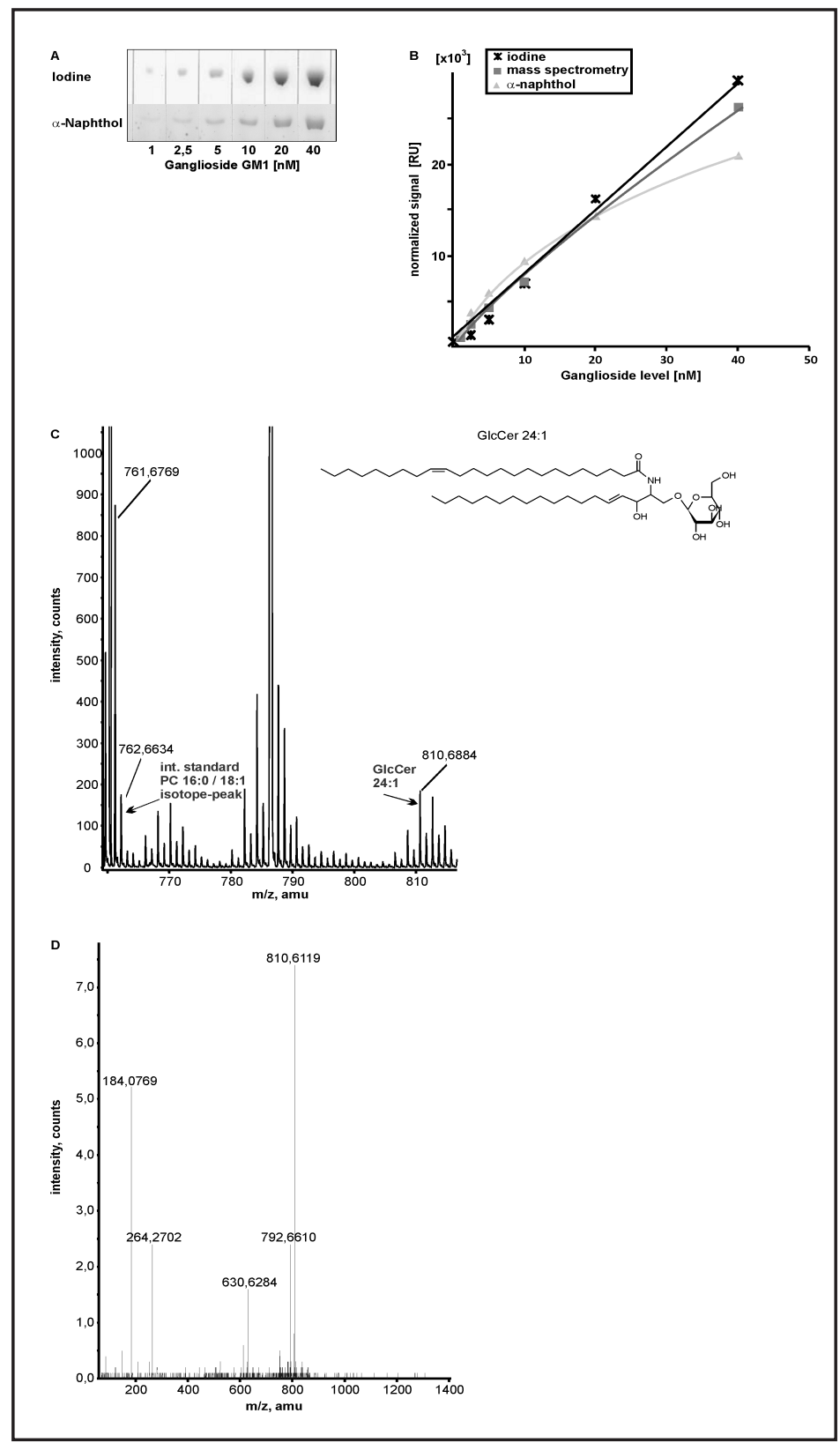

mutations, as we found increased GCS gene expression in transgenic mice expressing the APP Swedish double mutation (182.5; $\pm 62.2 \%$, p=0.233) (Fig. 5 A), increasing $\beta$-secretase cleavage of APP [58-60] and thus also causing FAD [61]. However, these results did not reach significance.

Beside the familial form of AD, we examined whether GCS might also be affected in the sporadic form of AD. Indeed, cortices of human post mortem AD brains showed a significantly increased level of total gangliosides (147.2\%, $\pm 12.3 \%, \mathrm{p}=0.033$ ) (Fig. $5 \mathrm{~B}$ and C). A more detailed analysis of 30 human post mortem AD brains compared to 14 age- and gendermatched human control brains (see Table 1) revealed that in two out of three brain regions GCS was increased (Fig. 5 D). Cerebellum and frontal cortex showed a significant increase in GCS expression (frontal cortex: 134.3\%, $\pm 16.9 \%$, $p=0.045$, cerebellum: $151.1 \%, \pm 23.0 \%$, $\mathrm{p}=0.028$ ) (Fig. 5 D) whereas in temporal cortex GCS expression was not significantly altered (temporal cortex: $82.6 \%, \pm 11.4 \%, \mathrm{p}=0.129$ ). We observed no sex-specific alterations in the GCS gene expression of temporal cortex and cerebellum whereas for frontal cortex 
we obtained sex-specific changes (Fig. 5 E). The observed significant increase in GCS gene expression of frontal cortex (males and females) (Fig. 5 D) is exclusively attributed to an elevated GCS gene transcription in males (Fig. 5 E). Control and AD brains used in this study showed no significant changes for age (Table 2) and pm-delay (Table 3).

\section{Discussion}

PS as an essential component of the $\gamma$-secretase complex affects ganglioside homeostasis by regulating GCS activity. In absence of PS or by $\gamma$-secretase inhibition, GCS activity is increased, resulting in elevated GlcCer and total ganglioside level. The change in GCS activity is accompanied by alterations in the expression level and protein level of GCS, suggesting that PS regulates GCS activity by affecting GCS expression. Comparable results were obtained in dependence of the APP family, indicating that the cleavage of APP by $\gamma$-secretase regulates GCS activity and that proteolytic cleavage products of APP are involved in the regulation of GCS. In line with these findings, it has been recently reported that differentiated PC12 cells, treated with the $\gamma$-secretase inhibitor DAPT, show an increase in ganglioside level in neuritic terminals [62], further strengthening that PS proteolytic activity alters ganglioside homeostasis. Additionally, we and others recently found that cleavage products of APP are involved in the regulation of several proteins and that this regulation is disturbed in absence of PS, in mutated PS or in AD [11, 30-32, 63-65]. Main focus was attended to the APP intracellular domain (AICD), which is released to the cytosol and discussed to be involved in gene transcription. Interestingly, multiple genes whose gene transcription is regulated by AICD belong to the sphingolipid pathway. AICD was found to decrease gene expression of the catalytic subunit of serine-palmitoyl-CoA transferase (SPT) [31] and to down regulate the expression of GD3-synthase (GD3S), the key enzyme converting $a$ - to $b$-series gangliosides [11]. Furthermore, AICD was reported to increase the expression level of the alkyl-dihydroxyacetone phosphate-synthase (AGPS), a rate limiting enzyme in plasmalogen synthesis [32], representing major brain lipids which are discussed to be altered in AD [66, 67]. AICD was also found to suppress the transcription of lipoprotein receptor LRP1 [68]. Beside AICD regulated gene transcription of lipid-related genes, AICD is discussed to be involved in the transcriptional regulation of several other proteins, e.g. neprilysin, an $A \beta$ degrading enzyme [69], and the mitochondrial master transcriptional coactivator PGC- $1 \alpha$, affecting mitochondrial energy metabolism [30]. As we found in the present study increased gene transcription of GCS in absence of PS or the APP family, one might speculate that AICD down regulates GCS gene expression. However, GCS gene expression was unaffected in APP/APLP2 deficient MEFs incubated with AICD peptides indicating that the $\gamma$-secretase dependent APP cleavage product AICD does not directly affect GCS gene expression. On the other hand GCS activity was decreased in AICD treated APP/APLP2 deficient cells supporting our hypothesis that AICD is involved in GCS regulation. One might speculate that AICD has a direct effect on GCS enzyme activity or alternatively, AICD regulates the gene transcription of additional proteins involved in regulating GCS expression. Potential AICD regulated proteins could be the transcription factor SP1 which is important for regulating GCS expression [70, 71] or further transcription factors as bindings sites for AhR, NF-kB, AP-2 and GATA-1 are also present in the GCS gene promoter [70, 72]. However, it has to be pointed out that, from the present data, we can not exclude that APP itself or additional $\gamma$-secretase substrates might be also involved in the regulation of GCS and further studies have to identify the exact role of AICD in the regulation of GCS. Furthermore, beside the involvement of APP cleavage products in GCS gene expression, additional mechanisms influencing GCS activity might exist. We recently found, that $\mathrm{A} \beta$ peptides also contribute to alterations in lipid homeostasis, by altering enzyme activity of GD3S, neutral sphingomyelinase and HMGCR $[10,11,73]$. In this context it should be mentioned that the observed increase in the ratio of $b / a$-series gangliosides in absence of PS1/2, APP/APLP2 or in PS1 FAD mutations is most likely caused by our previous findings showing that proteolytic products of APP diminish the turnover 
of $a$ - to $b$-series gangliosides, A $\beta$ peptides by decreasing GD3S enzyme activity, AICD by decreasing GD3S gene expression [11].

The essential role of APP in brain GCS regulation was further confirmed in vivo. Both APP-/- and cPS1/2-/- mice revealed an increase in GlcCer level. Utilizing APP-/- mice, which still express the other APP family members, suggests that the absence of APP alone is able to generate an effect on ganglioside synthesis. Nevertheless, we cannot exclude that other $\gamma$-secretase substrates might also influence ganglioside homeostasis. The effect strength in cPS1/2-/- mice was slightly less compared to APP deficient mouse brains. As PS1/2 knockout mice are lethal at e9.5 [48], conditional PS1 knock-out mice were used. These mice are completely deficient in PS2, but only the pyramidal neurons additionally lack PS1 [34]. Therefore, the remaining PS1 expression in some neurons, and thus $\gamma$-secretase activity, might be responsible for the less pronounced effect compared to APP deficient mice.

Summing it up, our results show that APP processing alters ganglioside de novo synthesis by inhibition of GCS. Notably, as mentioned above, it has been previously shown that also sphingolipid synthesis is affected by APP processing. Again, in line with the affected GCS activity, the committed step reaction of the sphingolipid synthesis, the SPT, was shown to be reduced by APP processing. The SPT catalyzes the condensation of serine and palmitoyl-CoA to generate 3-dehydroxysphinganine, which is further transformed to dihydroceramide. Desaturation of 3-dehydroxysphinganine leads to the generation of ceramide, which can be converted to sphingomyelin, sphingosine or various glycosphingolipids. The generation of glycosphingolipids starts with the initial binding of glucose to ceramide generating GlcCer by the GCS. As ceramide is the substrate for the GCS and ceramide levels strongly depend on the SPT activity, which was shown to be reduced in presence of AICD [31], the observed reduction in ganglioside de novo synthesis might be a combined effect of reduced SPT- and reduced GCS-activity. A recent study also suggests that this regulation is affected in AD [74]. Beside the enzymes SPT and GCS, GD3S has been shown to be regulated by A $\beta$ and AICD peptides, indicating that different enzymes of ganglioside synthesis are involved in the APP dependent regulation of ganglioside homeostasis, finally resulting in altered ganglioside homeostasis in APP or PS deficient cells. Furthermore, one has to take into consideration that changes in the GCS- and SPT-activity not only result in altered ganglioside homeostasis, but also affect ceramide and sphingomyelin levels. If GCS is increased in absence of APP or PS, the ceramide level should be decreased and as a consequence, the sphingomyelin level should be also decreased. However, in a previous study we observed increased levels of sphingomyelin in PS- or APP-deficient cells, which are caused by the lack of A $\beta$ peptides and have been shown to increase SMase activity. One might speculate that the potential decrease in ceramide and sphingomyelin levels caused by increased GCS activity in APPor PS-deficient cells, might be compensated by a reduced nSMase activity in absence of $\mathrm{A} \beta$ peptides. However, an increase in GCS activity and a decrease in nSMase activity would further drop the ceramide level. However, as we did not determine the ceramide levels in the present study to evaluate a potential influence on ceramides, further studies have to be performed. Beside the involvement of different enzymes in sphingolipid homeostasis, one has to consider that the amount of downstream compounds not only depend on GCS activity but also on other factors including the translocation of GlcCer from the cytosolic to the luminal site of the Golgi stacks. Furthermore, ganglioside synthesis strongly depends on the vesicular membrane flow through the Golgi apparatus [75].

Several lines of evidence suggest that ganglioside homeostasis is affected in AD, e.g. it has been reported that GlcCeror GM3 wereelevated in postmortem brains of AD patients supporting that ganglioside biosynthesis is affected during disease progression [22]. Results obtained by analyzing sporadic $\mathrm{AD}$ and FAD mutations in cell culture, transgenic mouse models or human post mortem brains suggest that the function of APP processing in regulating ganglioside homeostasis by GCS activity is disturbed in AD. Analyzing two different FAD mutations revealed that total gangliosides are increased, accompanied by an elevated GCS activity and expression. Some PS mutations increase the A $\beta 42$ level, but in parallel show decreased $\gamma$-secretase activity $[76,77]$ as we also found for the PS1 FAD mutations used in this study. In 
line with the inhibition of $\gamma$-secretase activity by utilizing a specific $\gamma$-secretase inhibitor, the PS mutation resulted in increased GCS activity suggesting that the reduced $\gamma$-secretase activity in PS-FAD might contribute to the observed effect. The effect found in MEFs expressing the PS-FAD mutations could also be found in vivo, in mouse brains expressing a PS mutation. Beside the effect of PS FAD mutations on GCS expression observed here, for two other PS FAD mutations (PS1 I143T and PS1 G384A) decreased GCS protein stability has been reported [78], further strengthening that ganglioside metabolism is dysregulated in AD.

Interestingly, mouse brains expressing the APPswe mutation showed a trend of increased GCS expression and analysis of three brain regions of $30 \mathrm{AD}$ post mortem brains, suffering from sporadic AD, and 14 control brains revealed increased GCS expression. These findings suggest that besides the $\gamma$-secretase activity, which is known to be affected in PS FAD mutations, an additional mechanism, being affected in $\mathrm{AD}$, has to exist. One might speculate that the proto-oncogene cFos could contribute to the observed upregulated GCS activity. It has been reported that cFos is elevated in AD [79] and is able to increase GCS activity [80], which might explain the observed findings. Nevertheless, it has to be mentioned that analyzing post mortem brains has clear limitations; a number of clinical, lifestyle, and post mortem variables may contribute to the observed findings. Despite these limitations, the present study employed a well-characterized set of brain tissues (see Table 1), where no statistically significant changes between the post mortem delay, the gender or the age of the $\mathrm{AD}$ and control group were observed. Additionally, no significant difference between mRNA level of actin of the $\mathrm{AD}$ and control group could be found, suggesting that the results obtained by RT-PCR were not or equally influenced by post mortem induced RNA degradation. Besides our findings that GCS is affected in AD, it has to be pointed out that additional key enzymes in ganglioside metabolism, e.g. sialyl transferase I and II (ST-I, ST-II) and $\beta-1,4-$ $\mathrm{N}$-acetylgalactosaminyltransferase 1 (GalNacT), are also linked to neurodegeneration [8183], explaining that especially ganglioside GM1 and GM2 are elevated in lipid raft fractions of tissues obtained from temporal or frontal cortex of AD patients [24]. Additionally, the ratio of the $a$ - and $b$-series gangliosides is reported to be changed by APP processing by an alteration in GD3S activity [11]. Moreover, it has to be taken into consideration that changes in ganglioside metabolism seem to be specific for different brain regions. An increase in GCS expression was found in frontal cortex and cerebellum, whereas temporal cortex showed no significant change in GCS expression. Notably, the increase in GCS gene expression observed for frontal cortex was attributed to an elevated GCS gene expression only in males whereas elevated GCS gene expression in cerebellum was caused by males and females. In this context it should be mentioned that we observed no changes in GCS gene expression in the temporal cortex of human AD brains, the brain region where AD pathology is most pronounced [84, 85]. Instead we found elevated GCS gene expression in the cerebellum, a brain region that is not affected by $\mathrm{AD}$ [86]. As the ganglioside pattern differs for individual brain regions [19, $20,87]$ our results suggest a brain region dependent regulation of ganglioside metabolism by APP processing. But obviously, GCS expression does not correlate with the plaque load of late $\mathrm{AD}$ as we found no changes for temporal cortex. In addition to a brain region dependent regulation of the ganglioside metabolism it has to be considered that aging itself affects ganglioside homeostasis $[19,20]$, which also influences the analysis of gangliosides in human post mortem tissues. This might also explain the results found by another study where GCS expression was reported to be decreased in frontal cortex of AD post mortem brains [88].

Our results show that APP processing affects GCS and that this regulation is affected in AD, resulting in altered ganglioside homeostasis. However, as discussed, changes in ganglioside levels not only depend on GCS activity. Additional enzymes such as SPT and GD3S are also involved in the regulation of sphingolipid and glycosphingolipid synthesis. In return it has been shown that gangliosides influence the release of A $\beta$ peptides. GM1 and GD3 incubation result in increased $A \beta$ production $[11,25]$, whereas GM3 decreases $A \beta$ production $[11,89]$. Furthermore, inhibition of GCS with DL-PDMP reduced A $\beta$ production by an intracellular accumulation of APP [90], suggesting that reducing ganglioside synthesis might have an anti-amyloidogenic potential and be beneficial in AD. However, as for example GM1, GD3 
and GM3 have different effects on $A \beta$ generation [11, 25, 89], further studies are necessary to clarify the effect of additional gangliosides, especially the major brain gangliosides, on $A \beta$ generation to identify the most promising step of inhibition in ganglioside de novo synthesis as therapeutic target for AD.

\section{Disclosure Statement}

The authors have no conflict of interest.

\section{Acknowledgements}

The research leading to these results has received funding from the EU FP7 project LipiDiDiet, Grant Agreement No. 211696 (TH), the DFG (HA2985/6-2) (TH), the Bundesministerium für Bildung, Forschung, Wissenschaft und Technologie via NGFNplus and KNDD (TH), and the HOMFOR (MG), the HOMFORexzellent 2011 (MG) (Saarland University research grants). We thank Thomas A. Bayer (Göttingen, Germany) for providing PSmutKI mice.

\section{References}

1 AD international, World Alzheimer Report: Alzheimer's Disease International Consortium, 2009.

2 Selkoe DJ: Cell biology of protein misfolding: The examples of Alzheimer's and Parkinson's diseases. Nat Cell Biol 2004;6:1054-1061.

-3 Masters CL, Simms G, Weinman NA, Multhaup G, McDonald BL, Beyreuther K: Amyloid plaque core protein in Alzheimer disease and Down syndrome. Proc Natl Acad Sci U S A 1985;82:4245-4249.

4 Zhang H, Ma Q, Zhang YW, Xu H: Proteolytic processing of Alzheimer's beta-amyloid precursor protein. J Neurochem 2012;120:S9-21.

5 Pardossi-Piquard R, Checler F: The physiology of the beta-amyloid precursor protein intracellular domain aicd. J Neurochem 2012;120:S109-124.

6 Steiner H, Fluhrer R, Haass C: Intramembrane proteolysis by gamma-secretase. J Biol Chem 2008;283:29627-29631.

7 St George-Hyslop PH, Petit A: Molecular biology and genetics of Alzheimer's disease. C R Biol 2005;328:119-130.

8 Brown MS, Ye J, Rawson RB, Goldstein JL: Regulated intramembrane proteolysis: A control mechanism conserved from bacteria to humans. Cell 2000;100:391-398.

-9 Wahrle S, Das P, Nyborg AC, McLendon C, Shoji M, Kawarabayashi T, Younkin LH, Younkin SG, Golde TE: Cholesterol-dependent gamma-secretase activity in buoyant cholesterol-rich membrane microdomains. Neurobiol Dis 2002;9:11-23.

10 Grimm MO, Grimm HS, Patzold AJ, Zinser EG, Halonen R, Duering M, Tschape JA, De Strooper B, Muller U, Shen J, Hartmann T: Regulation of cholesterol and sphingomyelin metabolism by amyloid-beta and presenilin. Nat Cell Biol 2005;7:1118-1123.

11 Grimm MO, Zinser EG, Grösgen S, Hundsdorfer B, Rothhaar TL, Burg VK, Kaestner L, Bayer TA, Lipp P, Muller U, Grimm HS, Hartmann T: Amyloid precursor protein (app) mediated regulation of ganglioside homeostasis linking Alzheimer's disease pathology with ganglioside metabolism. PLoS One 2012; 7:e34095.

12 Grimm MO, Kuchenbecker J, Grösgen S, Burg VK, Hundsdorfer B, Rothhaar TL, Friess P, de Wilde MC, Broersen LM, Penke B, Peter M, Vigh L, Grimm HS, Hartmann T: Docosahexaenoic acid reduces amyloid beta production via multiple pleiotropic mechanisms. J Biol Chem 2011;286:14028-14039.

13 Grimm MO, Rothhaar TL, Grösgen S, Burg VK, Hundsdorfer B, Haupenthal VJ, Friess P, Kins S, Grimm HS, Hartmann T: Trans fatty acids enhance amyloidogenic processing of the Alzheimer amyloid precursor protein (app). J Nutr Biochem 2012;23:1214-1223. 
Grimm et al.: Glucosylceramide Synthase and Alzheimer's Disease

14 Grimm MO, Grimm HS, Tomic I, Beyreuther K, Hartmann T, Bergmann C: Independent inhibition of Alzheimer disease beta- and gamma-secretase cleavage by lowered cholesterol levels. J Biol Chem 2008;283:11302-11311.

15 Grimm MO, Zimmer VC, Lehmann J, Grimm HS, Hartmann T: The impact of cholesterol, dha, and sphingolipids on Alzheimer's disease. BioMed Res Int 2013;2013:814390.

16 Fishman PH, Brady RO: Biosynthesis and function of gangliosides. Science 1976;194:906-915.

17 Landa CA, Maccioni HJ, Arce A, Caputto R: The biosynthesis of brain gangliosides. Separation of membranes with different ratios of ganglioside sialylating activity to gangliosides. Biochem J 1977; $168: 325-332$.

18 Degroote S, Wolthoorn J, van Meer G: The cell biology of glycosphingolipids. Semin Cell Dev Biol 2004;15:375-387.

19 Svennerholm L, Bostrom K, Jungbjer B, Olsson L: Membrane lipids of adult human brain: Lipid composition of frontal and temporal lobe in subjects of age 20 to 100 years. J Neurochem 1994;63:1802-1811.

20 Kracun I, Rosner H, Drnovsek V, Heffer-Lauc M, Cosovic C, Lauc G: Human brain gangliosides in development, aging and disease. Int J Dev Biol 1991;35:289-295.

21 Cutler RG, Kelly J, Storie K, Pedersen WA, Tammara A, Hatanpaa K, Troncoso JC, Mattson MP: Involvement of oxidative stress-induced abnormalities in ceramide and cholesterol metabolism in brain aging and Alzheimer's disease. Proc Natl Acad Sci U S A 2004;101:2070-2075.

-22 Chan RB, Oliveira TG, Cortes EP, Honig LS, Duff KE, Small SA, Wenk MR, Shui G, Di Paolo G: Comparative lipidomic analysis of mouse and human brain with Alzheimer disease. J Biol Chem 2012;287:2678-2688.

23 Gottfries CG, Karlsson I, Svennerholm L: Membrane components separate early-onset Alzheimer's disease from senile dementia of the Alzheimer type. International psychogeriatrics / IPA 1996;8:365-372.

24 Molander-Melin M, Blennow K, Bogdanovic N, Dellheden B, Mansson JE, Fredman P: Structural membrane alterations in Alzheimer brains found to be associated with regional disease development; increased density of gangliosides gm 1 and gm 2 and loss of cholesterol in detergent-resistant membrane domains. J Neurochem 2005;92:171-182.

25 Zha Q, Ruan Y, Hartmann T, Beyreuther K, Zhang D: Gm1 ganglioside regulates the proteolysis of amyloid precursor protein. Mol Psychiatry 2004;9:946-952.

26 Yanagisawa K, Odaka A, Suzuki N, Ihara Y: Gm1 ganglioside-bound amyloid beta-protein (a beta): A possible form of preamyloid in Alzheimer's disease. Nat Med 1995;1:1062-1066.

27 Krivit W, Desnick RJ, Lee J, Moller J, Wright F, Sweeley CC, Snyder PD Jr, Sharp HL: Generalized accumulation of neutral glycosphingolipids with gm2 ganglioside accumulation in the brain. Sandhoff's disease (variant of tay-sachs disease). Am J Med 1972;52:763-770.

-28 Tamboli IY, Hampel H, Tien NT, Tolksdorf K, Breiden B, Mathews PM, Saftig P, Sandhoff K, Walter J: Sphingolipid storage affects autophagic metabolism of the amyloid precursor protein and promotes abeta generation. J Neurosci 2011;31:1837-1849.

29 Keilani S, Lun Y, Stevens AC, Williams HN, Sjoberg ER, Khanna R, Valenzano KJ, Checler F, Buxbaum JD, Yanagisawa K, Lockhart DJ, Wustman BA, Gandy S: Lysosomal dysfunction in a mouse model of sandhoff disease leads to accumulation of ganglioside-bound amyloid-beta peptide. J Neurosci 2012;32:5223-5236.

-30 Robinson A, Grosgen S, Mett J, Zimmer VC, Haupenthal VJ, Hundsdorfer B, C PS, Slobodskoy Y, Muller UC, Hartmann T, Stein R, Grimm MO: Upregulation of pgc-1alpha expression by Alzheimer's diseaseassociated pathway: Presenilin 1/amyloid precursor protein (app)/intracellular domain of app. Aging cell 2013;13:263-272.

-31 Grimm MO, Grösgen S, Rothhaar TL, Burg VK, Hundsdorfer B, Haupenthal VJ, Friess P, Muller U, Fassbender K, Riemenschneider M, Grimm HS, Hartmann T: Intracellular app domain regulates serine-palmitoyl-coa transferase expression and is affected in Alzheimer's disease. Int J Alzheimers Dis 2011;2011:695413.

-32 Grimm MO, Kuchenbecker J, Rothhaar TL, Grösgen S, Hundsdorfer B, Burg VK, Friess P, Muller U, Grimm HS, Riemenschneider M, Hartmann T: Plasmalogen synthesis is regulated via alkyldihydroxyacetonephosphate-synthase by amyloid precursor protein processing and is affected in Alzheimer's disease. J Neurochem 2011;116:916-925.

-33 Ring S, Weyer SW, Kilian SB, Waldron E, Pietrzik CU, Filippov MA, Herms J, Buchholz C, Eckman CB, Korte M, Wolfer DP, Muller UC: The secreted beta-amyloid precursor protein ectodomain apps alpha is sufficient to rescue the anatomical, behavioral, and electrophysiological abnormalities of app-deficient mice. J Neurosci 2007;27:7817-7826. 
Grimm et al.: Glucosylceramide Synthase and Alzheimer's Disease

34 Saura CA, Chen G, Malkani S, Choi SY, Takahashi RH, Zhang D, Gouras GK, Kirkwood A, Morris RG, Shen J: Conditional inactivation of presenilin 1 prevents amyloid accumulation and temporarily rescues contextual and spatial working memory impairments in amyloid precursor protein transgenic mice. J Neurosci 2005;25:6755-6764.

35 Casas C, Sergeant N, Itier JM, Blanchard V, Wirths O, van der Kolk N, Vingtdeux V, van de Steeg E, Ret G, Canton T, Drobecq H, Clark A, Bonici B, Delacourte A, Benavides J, Schmitz C, Tremp G, Bayer TA, Benoit P, Pradier L: Massive ca1/2 neuronal loss with intraneuronal and n-terminal truncated abeta42 accumulation in a novel Alzheimer transgenic model. Am J Pathol 2004;165:1289-1300.

-36 Rothhaar TL, Grösgen S, Haupenthal VJ, Burg VK, Hundsdorfer B, Mett J, Riemenschneider M, Grimm HS, Hartmann T, Grimm MO: Plasmalogens inhibit app processing by directly affecting gamma-secretase activity in Alzheimer's disease. ScientificWorldJournal 2012;2012:141240.

-37 Livak KJ, Schmittgen TD: Analysis of relative gene expression data using real-time quantitative pcr and the 2(-delta delta c(t)) method. Methods 2001;25:402-408.

38 Grimm HS, Beher D, Lichtenthaler SF, Shearman MS, Beyreuther K, Hartmann T: Gamma-secretase cleavage site specificity differs for intracellular and secretory amyloid beta. J Biol Chem 2003;278:13077-13085.

39 Smith PK, Krohn RI, Hermanson GT, Mallia AK, Gartner FH, Provenzano MD, Fujimoto EK, Goeke NM, Olson BJ, Klenk DC: Measurement of protein using bicinchoninic acid. Anal Biochem 1985;150:76-85.

40 Bligh EG, Dyer WJ: A rapid method of total lipid extraction and purification. Can J Biochem Physiol 1959;37:911-917.

41 Matsuo N, Nomura T, Imokawa G: A rapid and simple assay method for udp-glucose:Ceramide glucosyltransferase. Biochim Biophys Acta 1992;1116:97-103.

-42 Jeckel D, Karrenbauer A, Burger KN, van Meer G, Wieland F: Glucosylceramide is synthesized at the cytosolic surface of various golgi subfractions. J Cell Biol 1992;117:259-267.

43 Bourteele S, Hausser A, Doppler H, Horn-Muller J, Ropke C, Schwarzmann G, Pfizenmaier K, Muller G: Tumor necrosis factor induces ceramide oscillations and negatively controls sphingolipid synthases by caspases in apoptotic kym-1 cells. J Biol Chem 1998;273:31245-31251.

44 Whitfield P, Johnson AW, Dunn KA, Delauche AJ, Winchester BG, Franklin RJ: Gm1-gangliosidosis in a cross-bred dog confirmed by detection of gm1-ganglioside using electrospray ionisation-tandem mass spectrometry. Acta Neuropathol (Berl) 2000;100:409-414.

45 Christie WW: Analysis of phospholipids and glycosyldiacylglycerols; Lipid analysis. Bridgwater, The Oily Press, 2003, pp 137-180.

46 Grimm MO, Paetzold AJ, Zinser EG, Ruppert T, Hartmann T: Linking Alzheimer's disease, ß-amyloid, and lipids: A technical approach.; in Xia W, Xu H (eds): Amyloid precursor protein - a practical approach. Boca Raton, Florida, CRC Press, 2005, vol 129-144.

47 Yanagisawa K: Role of gangliosides in Alzheimer's disease. Biochim Biophys Acta 2007;1768:1943-1951.

48 Donoviel DB, Hadjantonakis AK, Ikeda M, Zheng H, Hyslop PS, Bernstein A: Mice lacking both presenilin genes exhibit early embryonic patterning defects. Genes Dev 1999;13:2801-2810.

49 Svennerholm L, Bostrom K, Fredman P, Mansson JE, Rosengren B, Rynmark BM: Human brain gangliosides: Developmental changes from early fetal stage to advanced age. Biochim Biophys Acta 1989;1005:109-117.

50 De Strooper B, Iwatsubo T, Wolfe MS: Presenilins and gamma-secretase: Structure, function, and role in Alzheimer disease. Cold Spring Harb Perspect Med 2012;2:a006304.

51 Zheng H, Jiang M, Trumbauer ME, Sirinathsinghji DJ, Hopkins R, Smith DW, Heavens RP, Dawson GR, Boyce S, Conner MW, Stevens KA, Slunt HH, Sisoda SS, Chen HY, Van der Ploeg LH: Beta-amyloid precursor protein-deficient mice show reactive gliosis and decreased locomotor activity. Cell 1995;81:525-531.

52 Heber S, Herms J, Gajic V, Hainfellner J, Aguzzi A, Rulicke T, von Kretzschmar H, von Koch C, Sisodia S, Tremml P, Lipp HP, Wolfer DP, Muller U: Mice with combined gene knock-outs reveal essential and partially redundant functions of amyloid precursor protein family members. J Neurosci 2000;20:7951-7963.

53 Saura CA, Choi SY, Beglopoulos V, Malkani S, Zhang D, Shankaranarayana Rao BS, Chattarji S, Kelleher RJ, 3rd, Kandel ER, Duff K, Kirkwood A, Shen J: Loss of presenilin function causes impairments of memory and synaptic plasticity followed by age-dependent neurodegeneration. Neuron 2004;42:23-36.

54 Beglopoulos V, Sun X, Saura CA, Lemere CA, Kim RD, Shen J: Reduced beta-amyloid production and increased inflammatory responses in presenilin conditional knock-out mice. J Biol Chem 2004;279:4690746914. 
Grimm et al.: Glucosylceramide Synthase and Alzheimer's Disease

55 Kracun I, Kalanj S, Talan-Hranilovic J, Cosovic C: Cortical distribution of gangliosides in Alzheimer's disease. Neurochem Int 1992;20:433-438.

56 Bertram L, Tanzi RE: Thirty years of Alzheimer's disease genetics: The implications of systematic metaanalyses. Nat Rev Neurosci 2008;9:768-778.

57 Bekris LM, Yu CE, Bird TD, Tsuang DW: Genetics of Alzheimer disease. J Geriatr Psychiatry Neurol 2010;23:213-227.

58 Haass C, Lemere CA, Capell A, Citron M, Seubert P, Schenk D, Lannfelt L, Selkoe DJ: The swedish mutation causes early-onset Alzheimer's disease by beta-secretase cleavage within the secretory pathway. Nat Med 1995;1:1291-1296.

59 Reaume AG, Howland DS, Trusko SP, Savage MJ, Lang DM, Greenberg BD, Siman R, Scott RW: Enhanced amyloidogenic processing of the beta-amyloid precursor protein in gene-targeted mice bearing the swedish familial Alzheimer's disease mutations and a "humanized" abeta sequence. J Biol Chem 1996;271:23380-23388.

60 Thinakaran G, Teplow DB, Siman R, Greenberg B, Sisodia SS: Metabolism of the "swedish" amyloid precursor protein variant in neuro2a (n2a) cells. Evidence that cleavage at the "beta-secretase" site occurs in the golgi apparatus. J Biol Chem 1996;271:9390-9397.

61 Citron M, Oltersdorf T, Haass C, McConlogue L, Hung AY, Seubert P, Vigo-Pelfrey C, Lieberburg I, Selkoe DJ: Mutation of the beta-amyloid precursor protein in familial Alzheimer's disease increases beta-protein production. Nature 1992;360:672-674.

62 Oikawa N, Goto M, Ikeda K, Taguchi R, Yanagisawa K: The gamma-secretase inhibitor dapt increases the levels of gangliosides at neuritic terminals of differentiating pc12 cells. Neurosci Lett 2012;525:49-53.

63 von Rotz RC, Kohli BM, Bosset J, Meier M, Suzuki T, Nitsch RM, Konietzko U: The app intracellular domain forms nuclear multiprotein complexes and regulates the transcription of its own precursor. J Cell Sci 2004;117:4435-4448.

64 Ohkawara T, Nagase H, Koh CS, Nakayama K: The amyloid precursor protein intracellular domain alters gene expression and induces neuron-specific apoptosis. Gene 2011;475:1-9.

65 Hong Y, Beckett C, Belyaev ND, Turner AJ: The impact of amyloid precursor protein signalling and histone deacetylase inhibition on neprilysin expression in human prostate cells. Int J Cancer 2012;130:775-786.

66 Soderberg M, Edlund C, Kristensson K, Dallner G: Fatty acid composition of brain phospholipids in aging and in Alzheimer's disease. Lipids 1991;26:421-425.

67 Tully AM, Roche HM, Doyle R, Fallon C, Bruce I, Lawlor B, Coakley D, Gibney MJ: Low serum cholesteryl ester-docosahexaenoic acid levels in Alzheimer's disease: A case-control study. Br J Nutr 2003;89:483-489.

68 Liu Q Zerbinatti CV, Zhang J, Hoe HS, Wang B, Cole SL, Herz J, Muglia L, Bu G: Amyloid precursor protein regulates brain apolipoprotein e and cholesterol metabolism through lipoprotein receptor lrp1. Neuron 2007;56:66-78.

69 Grimm MO, Mett J, Stahlmann CP, Haupenthal VJ, Zimmer VC, Hartmann T: Neprilysin and abeta clearance: Impact of the app intracellular domain in nep regulation and implications in Alzheimer's disease. Front Aging Neurosci 2013;5:98.

70 Ichikawa S, Ozawa K, Hirabayashi Y: Molecular cloning and characterization of the mouse ceramide glucosyltransferase gene. Biochem Biophys Res Commun 1998;253:707-711.

-71 Uchida Y, Itoh M, Taguchi Y, Yamaoka S, Umehara H, Ichikawa S, Hirabayashi Y, Holleran WM, Okazaki T: Ceramide reduction and transcriptional up-regulation of glucosylceramide synthase through doxorubicinactivated sp1 in drug-resistant hl-60/adr cells. Cancer Res 2004;64:6271-6279.

72 Yu RK, Bieberich E, Xia T, Zeng G: Regulation of ganglioside biosynthesis in the nervous system. J Lipid Res 2004;45:783-793.

73 Zinser EG, Hartmann T, Grimm MO: Amyloid beta-protein and lipid metabolism. Biochim Biophys Acta 2007;1768:1991-2001.

74 Geekiyanage H, Chan C: Microrna-137/181c regulates serine palmitoyltransferase and in turn amyloid beta, novel targets in sporadic Alzheimer's disease. J Neurosci 2011;31:14820-14830.

75 Kolter T, Proia RL, Sandhoff K: Combinatorial ganglioside biosynthesis. J Biol Chem 2002;277:2585925862.

76 Wiley JC, Hudson M, Kanning KC, Schecterson LC, Bothwell M: Familial Alzheimer's disease mutations inhibit gamma-secretase-mediated liberation of beta-amyloid precursor protein carboxy-terminal fragment. J Neurochem 2005;94:1189-1201. 
77 Walker ES, Martinez M, Brunkan AL, Goate A: Presenilin 2 familial Alzheimer's disease mutations result in partial loss of function and dramatic changes in abeta 42/40 ratios. J Neurochem 2005;92:294-301.

78 Mutoh T, Kawamura N, Hirabayashi Y, Shima S, Miyashita T, Ito S, Asakura K, Araki W, Cazzaniga E, Muto E, Masserini M: Abnormal cross-talk between mutant presenilin 1 (i143t, g384a) and glycosphingolipid biosynthesis. FASEB J 2012;26:3065-3074.

79 Marcus DL, Strafaci JA, Miller DC, Masia S, Thomas CG, Rosman J, Hussain S, Freedman ML: Quantitative neuronal c-fos and c-jun expression in Alzheimer's disease. Neurobiol Aging 1998;19:393-400.

-80 Crespo PM, Silvestre DC, Gil GA, Maccioni HJ, Daniotti JL, Caputto BL: C-fos activates glucosylceramide synthase and glycolipid synthesis in pc12 cells. J Biol Chem 2008;283:31163-31171.

81 Niimi K, Nishioka C, Miyamoto T, Takahashi E, Miyoshi I, Itakura C, Yamashita T: Impairment of neuropsychological behaviors in ganglioside gm3-knockout mice. Biochem Biophys Res Commun 2011;406:524-528.

82 Wu G, Lu ZH, Kulkarni N, Amin R, Ledeen RW: Mice lacking major brain gangliosides develop Parkinsonism. Neurochem Res 2011;36:1706-1714.

83 Ohmi Y, Tajima O, Ohkawa Y, Yamauchi Y, Sugiura Y, Furukawa K: Gangliosides are essential in the protection of inflammation and neurodegeneration via maintenance of lipid rafts: Elucidation by a series of ganglioside-deficient mutant mice. J Neurochem 2011;116:926-935.

84 Prestia A, Baglieri A, Pievani M, Bonetti M, Rasser PE, Thompson PM, Marino S, Bramanti P, Frisoni GB: The in vivo topography of cortical changes in healthy aging and prodromal Alzheimer's disease. Supplements to Clin Neurophysiol 2013;62:67-80.

-85 Sturm VE, Yokoyama JS, Seeley WW, Kramer JH, Miller BL, Rankin KP: Heightened emotional contagion in mild cognitive impairment and Alzheimer's disease is associated with temporal lobe degeneration. Proc Natl Acad Sci U S A 2013;110:9944-9949.

-86 Larner AJ: The cerebellum in Alzheimer's disease. Dement Geriatr Cogn Disord 1997;8:203-209.

-87 Kracun I, Rosner H, Cosovic C, Stavljenic A: Topographical atlas of the gangliosides of the adult human brain. J Neurochem 1984;43:979-989.

88 Marks N, Berg MJ, Saito M: Glucosylceramide synthase decrease in frontal cortex of Alzheimer brain correlates with abnormal increase in endogenous ceramides: Consequences to morphology and viability on enzyme suppression in cultured primary neurons. Brain Res 2008;1191:136-147.

89 Bernardo A, Harrison FE, McCord M, Zhao J, Bruchey A, Davies SS, Jackson Roberts L $2^{\text {nd }}$, Mathews PM, Matsuoka Y, Ariga T, Yu RK, Thompson R, McDonald MP: Elimination of gd3 synthase improves memory and reduces amyloid-beta plaque load in transgenic mice. Neurobiol Aging 2009;30:1777-1791.

$\$ 90$ Tamboli IY, Prager K, Barth E, Heneka M, Sandhoff K, Walter J: Inhibition of glycosphingolipid biosynthesis reduces secretion of the beta-amyloid precursor protein and amyloid beta-peptide. J Biol Chem 2005;280:28110-28117. 